\title{
Pengaruh Literasi Keuangan dan Financial Technology Terhadap Inklusi Keuangan pada Masyarakat Pekanbaru (Studi pada Investor Saham Syariah di Pekanbaru)
}

\author{
Yolanda Atika Safira ${ }^{1}$, Yulia Efni ${ }^{2}$ Fitri $^{3}$ \\ Universitas Riau, Pekanbaru, Riau, Indonesia
}

\begin{abstract}
ABSTRAK : Penelitian ini bertujuan untuk menguji pengaruh dari literasi keuangan dan penggunaan aplikasi online trading terhadap inklusi keuangan pada investor saham syariah di Pekanbaru. Sampel yang digunakan dalam penelitian ini adalah 150 investor saham syariah di Pekanbaru yang menggunakan aplikasi online trading dalam bertransaksi saham. Pemilihan sampel menggunakan metode non-probability sampling dan teknik purposive sampling. Penelitian ini menggunakan Structural Equation Modeling-Partial Least Square (SEM-PLS) dalam menganalis data. Hasil penelitian ini menunjukan bahwa literasi keuangan berpengaruh positif dan signifikan terhadap inklusi keuangan pada Investor saham syariah di Pekanbaru dan financial technology berpengaruh positif dan signifikan terhadap Investor saham syariah di Pekanbaru.
\end{abstract}

Kata Kunci : Literasi Keuangan, Financial Technology, Inklusi Keuangan, Online Trading System, Sharia Stock Investors

\begin{abstract}
This study aims to examine the effect of financial literacy and the use of online trading applications on financial inclusion of sharia stock Investors in Pekanbaru. The sample used in this study was 150 sharia stock Investors in Pekanbaru who use online trading applications in stock transactions. Sampling uses non-probability sampling methods and purposive sampling techniques. The data in this study are quantitative data obtained using a questionnaire and processed by using Partial Least Square Structural Equation Modeling (PLS-SEM). The results of this study indicate that financial literacy has a positive and significant effect on financial inclusion of sharia stock investors in Pekanbaru and financial technology has a positive and significant effect on sharia stock investors in Pekanbaru.
\end{abstract}

Keywords: Literacy Keuangan, Financial Technology, Finacial Inklusi, Online Trading System, Sharia Stock Investors

Email Address : yolandaatika@gmail.com

\section{Pendahuluan}

Keberadaan pasar modal
menjadi salah satu hal yang sangat
penting untuk menggerakan roda
perekonomian, karena berfungsi sebagai
sarana pendanaan modal bagi sebuah
perusahaan dan juga sarana investasi

bagi masyarakat. Selain pasar modal konvensional, terdapat pasar modal syariah yang dimulai sejak tahun 1997 di Indonesia. Pada umumnya, kegiatan dalam pasar modal syariah tidak memiliki perbedaan dengan pasar modal konvensional, hanya saja dalam 
pengaplikasiannya memiliki beberapa syarat khusus, yaitu produk - produk yang diperjualbelikan serta mekanisme bertransaksinya tidak melanggar prinsip - prinsip syariah, yang mana prinsip tersebut bersumber pada Al-Quran dan Hadist sebagai sumber hukum.

\section{Perkembangan dalam pasar} modal syariah dapat dilihat dari banyaknya jumlah saham syariah yang beredar, dalam Daftar Efek Syariah (DES) per Desember 2019, terdapat 445 jenis saham syariah dari total jumlah emiten 659 yang ada di BEI. Selain itu nilai kapitalisasi pasar saham syariah, dalam 5 tahun terakhir mengalami peningkatan dari tahun 2014 sebesar 2.947 triliun meningkat pada tahun 2018 sebesar 3.667 triliun.

Perkembangan pasar modal syariah di Indonesia dari data-data tompersebut dapat dikategorikan positif, namun keberadaan pasar modal syariah sebagai sarana investasi bagi masyarakat di Indonesia masih dapat terbilang rendah peminat. Pada tahun 2018 komposisi investor saham syariah hanya sekitar 5,7\% dari total investor saham pada pasar modal. Kurangnya pemahaman masyarakat mengenai pasar modal syariah diindikasikan sebagai keraguan bagi investor untuk menanamkan modalnya pada pasar modal. Pemahaman terhadap pasar modal merupakan terminologi dari istilah literasi keuangan. Dalam hasil Strategi Nasional Literasi Keuangan Indonesia (SNLKI) yang dilakukan oleh Otoritas Jasa Keuangan (OJK) tahun 2017 menghasilkan indeks tingkat literasi keuangan sektor pasar modal yaitu sebesar $4,4 \%$, angka ini menjadi yang terendah dibandingkan sektor industri keuangan lainnya. Literasi keuangan merupakan suatu hal yang seharusnya menjadi dasar tiap - tiap individu atau masyarakat dalam mengelola urusan keuangan. Otoritas Jasa Keuangan sebagai lembaga yang mengatur seluruh kegiatan di sektor keuangan bertekad mewujudkan sistem keuangan yang berkelanjutan dan stabil, menyatakan bahwa literasi keuangan akan diikuti oleh tingkat inklusi keuangan.

Dalam mendorong peningkatan inklusi keuangan, berbagai strategi diterapkan dengan menyesuaikan perkembangan zaman. Salah satunya dengan memanfaatkan jaringan internet. Penerapan jaringan internet pada layanan keuangan digital atau yang disebut sebagai financial technology (Fintech), dianggap sebagai cara yang efektif untuk menyediakan peluang dalam mendorong inklusi keuangan, yaitu dengan meringankan biaya transaksi keuangan tanpa harus menyediakan layanan keuangan tradisional dalam bentuk jaringan kantor. Fintech dalam dunia perbankan telah memberikan dampak yang sangat signifikan, dimana Fintech mampu menjangkau masyarakat yang belum dapat dijangkau oleh perbankan, (Kajian Stabilitas Keuangan Bank Indonesia, 2017). Hadirnya fintech di pasar modal memberikan kemudahan bertransaksi seperti contohnya Online Trading System, yang telah menjadi bagian penting dalam perkembangan pasar modal saat ini. Banyak perusahaan sekuritas yang ada di Indonesia saat ini menawarkan sistem online trading sebagai salah satu fasilitas penunjang bagi para investor pada perusahaan sekuritasnya. Untuk investor saham syariah, terdapat pula Syariah Online Trading System (SOTS), dimana sistem tersebut telah terintegrasi dengan prinsip syariah yang berlaku.

Berdasarkan uraian yang telah dijelaskan diatas, pada akhirnya penelitian ini dirumuskan dalam bentuk pertanyaan penelitian sebagai berikut:

1. Apakah literasi keuangan berpengaruh terhadap inklusi keuangan pada investor saham syariah di Pekanbaru?

2. Apakah financial technology berpengaruh terhadap inklusi keuangan 
pada investor saham syariah di Pekanbaru?

\section{Landasan Teori}

\section{Literasi Keuangan}

$$
\text { POJK Nomor } 76
$$

/POJK.07/2016 menyatakan literasi keuangan adalah pengetahuan, keterampilan, dan keyakinan, yang mempengaruhi sikap dan perilaku untuk meningkatkan kualitas pengambilan keputusan dan pengelolaan keuangan dalam rangka mencapai kesejahteraan. Literasi keuangan dapat diartikan pula sebagai kecakapan atau kesanggupan individu dalam hal keuangan dimana ia akan mampu melihat uang dengan sudut pandang yang berbeda dan memiliki kendali atas kondisi keuangannya, (Djawahir, 2018), (Xu dan Zia, 2012). Organisation for Economic Cooperation and Development International Network on Financial Education atau OECD/INFE mengembangkan survei literasi keuangan internasional yang dapat digunakan dengan latar belakang negara yang sangat berbeda di berbagai negara. Terdapat 3 instument pengukur literasi keuangan menurut guidebook OECD/INFE 2016, yaitu:

\section{Pengetahuan Keuangan}

(Financial Knowledge), pengetahuan keuangan dihitung sebagai jumlah tanggapan atau jawaban responden terhadap pernyataan mengenai 4 topik pengetahuan keuangan, yaitu: nilai waktu uang, resiko dan laba, definisi inflasi dan diversifikasi.

2. Perilaku Keuangan (Financial Behavior), tingkat perilaku keuangan mengacu pada sejumlah pernyataan untuk mengeksplorasi sejauh mana seseorang berperilaku dalam cara melek keuangan.

3. Sikap keuangan (Financial Attitude), terkait dengan bagaimana responden dalam memprioritaskan keuangan jangka pendek daripada membuat rencana jangka panjang.

\section{Financial Technology}

Financial Technology (Fintech) atau sering disebut juga dengan digital keuangan merupakan inovasi sistem keuangan secara digital agar masyarakat dapat dengan mudah mengakses produk dan layanan keuangan dan melemahkan barrier to entry, (Bank Indonesia, 2016). Financial technology dapat mengubah cara perusahaan dalam membuat dan menyediakan produk atau layanan, dapat menangani masalah privasi, regulasi, dan tantangan hukum, serta memberikan peluang untuk pertumbuhan yang inklusif, (Dhar dan Stein, 2017). Financial technology dalam penelitian ini adalah produk digital keuangan pada pasar modal berupa produk aplikasi online trading saham. Dimana, online trading sistem adalah suatu sistem perdagangan secara online melalui perangkat teknologi internet, dimana dengan sistem ini investor tidak perlu lagi datang atau menelepon kantor pialang (broker) pada perusahaan sekuritasnya, karena eksekusi investasi serta semua informasi harga dapat dilakukan dimana saja, kapan saja, selama akses tersebut tetap terhubung dengan koneksi internet.

$$
\text { Untuk mengukur adopsi }
$$
penggunaan Online Trading System, peneliti mengadopsi indikator dari berbagai penelitian dahulu, (Roca, García dan de la Vega, 2009), (Lee, 2009) dan (Ramayah et al., 2009). Bedasarkan berbagai penelitian sebelumnya, untuk menyesuaikan dengan penelitian ini, peneliti menetapkan pengukuran adopsi penggunaan online trading system sebagai produk dari financial technology di pasar modal Indonesia, adalah sebagai berikut:

\section{1. $\quad$ Perceived Ease of Use (PEU)}

Perceived Ease of Use atau persepsi kemudahan penggunaan didefinisikan 
sebagai sejauh mana seseorang percaya bahwa menggunakan sistem tertentu akan bebas dari usaha.

\section{2. $\quad$ Perceived Usefulness (PU)}

Perceived Usefulness atau presepsi kegunaan mengacu pada tingkat dimana seseorang percaya bahwa dengan menggunakan sistem tertentu akan meningkatkan kinerja pekerjaannya.

\section{Attitude Toward Using}

Attitude Toward Using atau sikap terhadap penggunaan mengacu pada perasaan positif atau negatif individu dalam menggunakan teknologi

\section{Subjective Norms}

Subjective norms adalah persepsi seseorang terhadap harapan dari orangorang yang berpengaruh dalam kehidupannya mengenai apa yang dilakukan atau tidak dilakukannya dalam menggunakan teknologi.

\section{Trust}

Trust adalah harapan yang dipilih oleh orang lain untuk percaya tidak akan berperilaku oportunistik

\section{Perceived Risk}

Perceived Risk adalah risiko yang dirasakan sebagai semacam kerugian subyektif yang diharapkan atau kemungkinan kerugian yang didapatkan saat mengejar hasil yang diinginkan.

\section{7. $\quad$ Perceived Benefit}

Perceived Benefit adalah persepsi positif yang disebabkan oleh suatu aksi dalam hal ini keuntungan langsung mengacu pada manfaat langsung dan nyata yang akan dinikmati pelanggan dengan menggunakan perdagangan online.

\section{Inklusi Keuangan}

Berdasarkan Peraturan Presiden Nomor 82 Tahun 2016 tentang Strategi Nasional Keuangan Inklusif, inklusi keuangan adalah sebuah kondisi dimana setiap anggota masyarakat mempunyai akses terhadap berbagai layanan keuangan formal yang berkualitas, tepat waktu, lancar, dan aman dengan biaya terjangkau sesuai dengan kebutuhan dan kemampuan masing-masing. Definisi lain dari inklusi keuangan menurut Allen et al., (2015) inklusi keuangan didefinisikan sebagai penggunaan layanan keuangan formal yang membawa manfaat kepada para individu seperti penggunaan akun bank, kartu debit dan kredit dan lainnya. Akses di pasar modal merujuk pada jumlah total orang yang menjadi investor di pasar modal. Pengukuran inklusi keuangan menggunakan adopsi pengukuran OECD/INFE 2016 yang dimodifikasi sesuai konteks penelitian, yaitu:

\section{Product Holding}

Product Holding bertujuan untuk mengidentifikasi produk yang saat ini dimiliki oleh responden, dengan melihat apakah konsumen setidaknya sadar terhadap produk investasi yang tersedia di Indonesia.

\section{Product Awareness}

Kesadaran akan penggunaan produk keuangan adalah hal yang penting dalam memulai langkah untuk peningkatan inklusi keuangan, dimana dengan kesadaran ini akan mencegah terjadinya kesalahan dalam pemilihan dan membantu penyedia produk keuangan (supply-side) untuk mengetahui permintaan dari masyarakat (demandside).

\section{Product Choice}

Dalam memilih produk keuangan, inklusi keuangan akan menguntungkan konsumen jika mereka terus memantau produk mereka, dan melakukan pertimbangan bila terjadi perubahan ketika terdapat produk atau layanan baru yang tersedia atau saat struktur harga berubah.

\section{Model Penelitian dan Hipotesis}

Gambar 1. Model Penelitian 


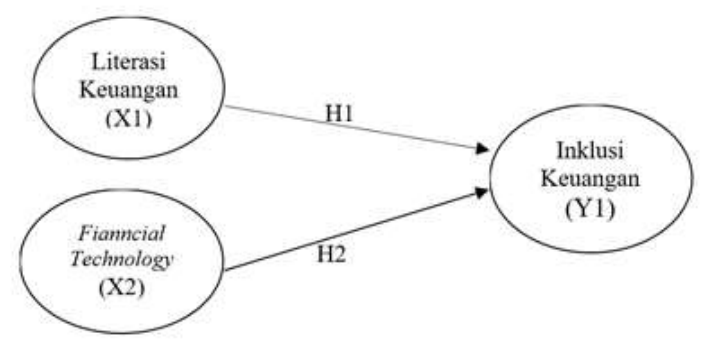

H1: Literasi keuangan berpengaruh terhadap Inklusi keuangan pada Investor Saham Syariah di Pekanbaru

H2: Financial Technology berpengaruh terhadap Inklusi Keuangan pada Investor Saham Syariah di Pekanbaru

\section{Metodologi Penelitian}

\section{Jenis dan Sumber Data Penelitian}

Populasi dalam penelitian ini adalah investor saham syariah yang berada di Pekanbaru. Metode pengambilan sampel adalah purposive sampling. Berdasarkan kriteria pemilihan sampel yang telah ditentukan, yaitu: 1. Berdomisili di Pekanbaru, 2. Memiliki pengalaman investasi paling minim 6 bulan, dan 3. Menggunakan aplikasi syariah online trading system. Penentuan jumlah sampel minimal pada penelitian ini menggunakan rumus Hair et al. dimana jumlah sampel sebaiknya lebih besar atau sama dengan 100 dan menyesuaikan jumlah sampel dengan jumlah indikator yaitu 5-10x jumlah indikator (30) x $5=150$ responden. Teknik pengumpulan data pada penelitian ini menggunakan kuesioner dengan pengisian data melalui google form yang disebarkan melalui platform online seperti instagram, twitter, whatsapp dan facebook, kepada komunitas - komunitas investor saham.

\section{Metode Analisa dan Hipotesis Penelitian}

Metode dalam penelitian ini menggunakan Structural Equation Modeling-Partial Least Square (SEMPLS). Menurut Ghozali (2015) PLS merupakan salah satu metode statistika yang secara simultan dapat melakukan persamaan struktural pengujian model pengukuran sekaligus pengujian model struktural. PLS dapat digunakan untuk mengkonfirmasi teori dan digunakan untuk menjelaskan ada tidaknya hubungan antar variabel laten.

\section{Hasil Penelitian dan Pembahasan}

Uji Validitas Konvergen (Convergent Validity)

Tabel 1. Hasil Uji Validitas Konvergen

\begin{tabular}{|c|c|c|c|c|c|c|c|c|c|}
\hline Variabel & Indikator & $\begin{array}{c}\text { Loading } \\
\text { Factor }\end{array}$ & $\begin{array}{c}\text { Nilai } \\
\text { Keritis }\end{array}$ & Ket & Variabel & Indikator & $\begin{array}{c}\text { Loading } \\
\text { Factor }\end{array}$ & $\begin{array}{l}\text { Nilai } \\
\text { Keritis }\end{array}$ & Ket \\
\hline \multirow{10}{*}{$\begin{array}{l}\text { Literasi } \\
\text { Keuangan }\end{array}$} & LK1 & 0,734 & 0,7 & Valid & & FT6 & 0,794 & 0,7 & Valid \\
\hline & LK2 & 0,752 & 0,7 & Valid & & FT7 & 0,767 & 0,7 & Valid \\
\hline & LK3 & 0,81 & 0,7 & Valid & & FT8 & $\mathbf{0 , 8 4}$ & 0,7 & Valid \\
\hline & LK4 & 0,738 & 0,7 & Valid & & FT9 & 0,794 & 0,7 & Valid \\
\hline & LK5 & 0,815 & 0,7 & Valid & & FT10 & 0,715 & 0,7 & Valid \\
\hline & LK6 & 0,725 & 0,7 & Valid & & FT11 & 0,729 & 0,7 & Valid \\
\hline & LK7 & 0,742 & 0,7 & Valid & & FT2 & 0,805 & 0,7 & Valid \\
\hline & LK8 & 0,737 & 0,7 & Valid & & FT13 & 0,85 & 0,7 & Valid \\
\hline & LK9 & 0,78 & 0,7 & Valid & & FT14 & 0,774 & 0,7 & Valid \\
\hline & LK10 & 7,69 & 0,7 & Valid & & FT15 & 0,723 & 0,7 & Valid \\
\hline \multirow{3}{*}{$\begin{array}{l}\text { Financial } \\
\text { Technology }\end{array}$} & FT1 & 0,769 & 0,7 & Valid & \multirow{3}{*}{$\begin{array}{l}\text { Inklusi } \\
\text { Keuangan }\end{array}$} & IK1 & 0,771 & 0,7 & Valid \\
\hline & FT2 & 0,804 & 0,7 & Valid & & IK2 & 0,777 & 0,7 & Valid \\
\hline & FT3 & 0,804 & 0,7 & Valid & & IK3 & 0,863 & 0,7 & Valid \\
\hline
\end{tabular}


FE Universitas Maritim Raja Ali Haji

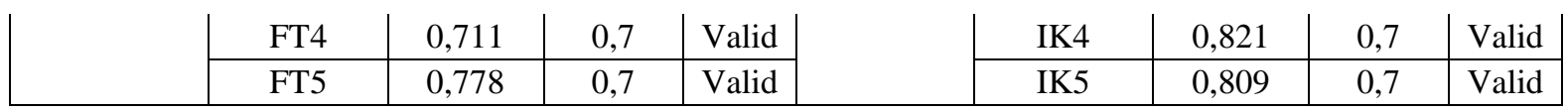

Sumber: Data Olahan (2020)

Dari tabel 1 di atas dapat diketahui bahwa indikator masingmasing konstruk memberikan nilai convergent validity yang tinggi, yaitu seluruh indikator di atas 0.70 . Hasil ini memberikan makna bahwa seluruh indikator menunjukkan convergent validity yang baik.

\section{Uji Validitas Diskriminan (Discriminant Validity)}

Tabel 2. Hasil Uji Validitas Diskriminan

\begin{tabular}{|c|c|c|c|c|c|c|c|}
\hline $\begin{array}{c}\text { Indikato } \\
\text { r }\end{array}$ & $\begin{array}{c}\text { Lit.Ke } \\
\mathbf{u}\end{array}$ & $\begin{array}{c}\text { Fin.Tec } \\
\text { h }\end{array}$ & $\begin{array}{c}\text { Ink.Ke } \\
\mathbf{u}\end{array}$ & $\begin{array}{c}\text { Indikato } \\
\mathbf{r}\end{array}$ & $\begin{array}{c}\text { Lit.Ke } \\
\mathbf{u}\end{array}$ & $\begin{array}{c}\text { Fin.Tec } \\
\mathbf{h}\end{array}$ & $\begin{array}{c}\text { Ink.Ke } \\
\mathbf{u}\end{array}$ \\
\hline LK1 & $\mathbf{0 , 7 3 4}$ & $-0,035$ & $-0,105$ & FT6 & 0,018 & $\mathbf{0 , 7 9 4}$ & 0,18 \\
\hline LK2 & $\mathbf{0 , 7 5 2}$ & 0,128 & $-0,109$ & FT7 & $-0,101$ & $\mathbf{0 , 7 6 7}$ & 0,055 \\
\hline LK3 & $\mathbf{0 , 8 1}$ & 0,103 & 0 & FT 8 & 0,039 & $\mathbf{0 , 8 4}$ & $-0,057$ \\
\hline LK4 & $\mathbf{0 , 7 3 8}$ & $-0,104$ & 0,15 & FT9 & 0,056 & $\mathbf{0 , 7 9 4}$ & 0,133 \\
\hline LK5 & $\mathbf{0 , 8 1 5}$ & $-0,102$ & 0,056 & FT10 & 0,125 & $\mathbf{0 , 7 1 5}$ & $-0,252$ \\
\hline LK6 & $\mathbf{0 , 7 2 5}$ & 0,076 & $-0,006$ & FT11 & $-0,008$ & $\mathbf{0 , 7 2 9}$ & $-0,163$ \\
\hline LK7 & $\mathbf{0 . 7 4 2}$ & $-0,153$ & 0,028 & FT2 & 0,066 & $\mathbf{0 , 8 0 5}$ & 0,013 \\
\hline LK8 & $\mathbf{0 , 7 3 7}$ & $-0,149$ & 0,231 & FT13 & $-0,119$ & $\mathbf{0 , 7 5}$ & 0,089 \\
\hline LK9 & $\mathbf{0 , 7 8}$ & 0,085 & $-0,169$ & FT14 & $-0,172$ & $\mathbf{0 , 7 7 4}$ & 0,102 \\
\hline LK10 & $\mathbf{0 , 7 6 9}$ & 0,139 & $-0,068$ & FT15 & $-0,141$ & $\mathbf{0 , 7 2 3}$ & 0,124 \\
\hline FT1 & 0,084 & $\mathbf{0 , 7 6 9}$ & $-0,156$ & IK1 & $-0,151$ & $-0,044$ & $\mathbf{0 , 7 7 1}$ \\
\hline FT2 & 0,084 & $\mathbf{0 , 8 0 4}$ & $-0,098$ & IK2 & 0,084 & 0,091 & $\mathbf{0 , 7 7 7}$ \\
\hline FT3 & 0,155 & $\mathbf{0 , 8 0 4}$ & 0,074 & IK3 & $-0,028$ & 0,05 & $\mathbf{0 , 8 6 3}$ \\
\hline FT4 & 0,042 & $\mathbf{0 , 7 1 1}$ & 0,059 & IK4 & 0,02 & $-0,09$ & $\mathbf{0 , 8 2 1}$ \\
\hline FT5 & 0,045 & $\mathbf{0 , 7 7 8}$ & $-0,12$ & IK5 & 0,073 & $-0,007$ & $\mathbf{0 , 8 0 9}$ \\
\hline
\end{tabular}

Sumber: Data Olahan (2020)

Dari tabel 2 diatas dapat dilihat bahwa nilai loading factor untuk setiap indikator dari masing-masing variable laten telah memiliki nilai loading factor yang paling besar dibanding nilai loading variabel laten lainnya. Hal ini menunjukan bahwa setiap variabel laten telah memiliki discriminant validity yang baik.

\section{Tabel 3. Hasil Uji Validitas Diskriminan Square Root Of Average (AVE)}

\begin{tabular}{|l|c|c|c|}
\hline $\begin{array}{c}\text { Variabe } \\
\text { l }\end{array}$ & $\begin{array}{c}\text { Lit.Ke } \\
\mathbf{u}\end{array}$ & $\begin{array}{c}\text { Fin.Te } \\
\mathbf{c}\end{array}$ & $\begin{array}{c}\text { Ink.Ke } \\
\mathbf{u}\end{array}$ \\
\hline Lit.Keu & $\mathbf{0 , 7 6 1}$ & 0,202 & 0,632 \\
\hline Fin.Tec & 0,202 & $\mathbf{0 , 7 7 2}$ & 0,483 \\
\hline Ink.Keu & 0,632 & 0,483 & $\mathbf{0 , 8 0 9}$ \\
\hline \multicolumn{3}{|l}{ Sumber: Data Olahan (2020) }
\end{tabular}

Dari tabel 3 diatas dapat diketahui bahwa nilai square root atas $A V E$ sepanjang garis diagonal lebih besar korelasinya antara satu konstruk dengan yang lainnya, sehingga dapat disimpulkan bahwa konstruk memiliki tingkat validitas yang baik.

\section{Uji Reliabilitas}

Tabel 4. Hasil Uji Reliabilitas

\begin{tabular}{|l|c|c|}
\hline \multicolumn{1}{|c|}{ Variabel } & $\begin{array}{c}\text { Cronbach's } \\
\text { Alpha }\end{array}$ & $\begin{array}{c}\text { Composite } \\
\text { Reliability }\end{array}$ \\
\hline $\begin{array}{l}\text { Literasi } \\
\text { Keuangan }\end{array}$ & 0,919 & 0,932 \\
\hline $\begin{array}{l}\text { Financial } \\
\text { Technology }\end{array}$ & 0,951 & 0,957 \\
\hline $\begin{array}{l}\text { Inkluasi } \\
\text { Keuangan }\end{array}$ & 0,867 & 0,904 \\
\hline \multicolumn{2}{|l|}{ Sumber: Data Olahan (2020) } \\
\hline
\end{tabular}

Dari tabel 4 diatas menunjukkan bahwa nilai composite reliability untuk 
semua konstruk adalah $>0,7$ dan cronbach's alpha > 0,6 yang menunjukkan bahwa semua konstruk pada model yang diestimasi memenuhi kriteria (reliable).

\section{Uji Kecocokan Model (goodness of fit)}

Tabel 5. Model fit dan Quality Indexes

\begin{tabular}{|c|c|c|c|c|}
\hline $\begin{array}{l}\text { Model Fit and } \\
\text { Quality Indices }\end{array}$ & $\begin{array}{l}\text { Indek } \\
\mathrm{s}\end{array}$ & P-value & Kriteria & Ket \\
\hline APC & 0,468 & $\mathrm{P}<0,001$ & $\mathrm{P}<0,05$ & $\begin{array}{c}\text { Diteri } \\
\text { ma }\end{array}$ \\
\hline ARS & 0,574 & $\mathrm{P}<0,001$ & $\mathrm{P}<0,05$ & $\begin{array}{c}\text { Diteri } \\
\text { ma }\end{array}$ \\
\hline AARS & 0,568 & $\mathrm{P}<0,001$ & $\mathrm{P}<0,05$ & $\begin{array}{c}\text { Diteri } \\
\text { ma }\end{array}$ \\
\hline AVIF & 1,105 & \multicolumn{2}{|c|}{$\leq 5$ dan idealnya $\leq 3,3$} & $\begin{array}{c}\text { Diteri } \\
\text { ma }\end{array}$ \\
\hline AFVIF & 1,725 & \multicolumn{2}{|c|}{$\leq 5$ dan idealnya $\leq 3,3$} & $\begin{array}{c}\text { Diteri } \\
\text { ma }\end{array}$ \\
\hline GoF & 0,591 & \multicolumn{2}{|c|}{$\begin{array}{c}\text { Small } \geq 0,1 ; \text { Medium } \geq 0,25 ; \\
\text { Large } \geq 0,36\end{array}$} & Large \\
\hline SPR & 1,000 & \multicolumn{2}{|c|}{$\geq 0,7$ dan idealnya $=1$} & $\begin{array}{c}\text { Diteri } \\
\text { ma }\end{array}$ \\
\hline RSCR & 1,000 & \multicolumn{2}{|c|}{$\geq 0,9$ dan idealnya 1} & $\begin{array}{l}\text { Diteri } \\
\text { ma }\end{array}$ \\
\hline SSR & 1,000 & \multicolumn{2}{|c|}{$\geq 0,7$} & $\begin{array}{l}\text { Diteri } \\
\text { ma }\end{array}$ \\
\hline NLBCDR & 1,000 & \multicolumn{2}{|c|}{$\geq 0,7$} & $\begin{array}{l}\text { Diteri } \\
\text { ma }\end{array}$ \\
\hline
\end{tabular}

Sumber: Data Olahan (2020)

Dari tabel 5.15 di atas dapat diketahui nilai average path coefficient (APC) sebesar 0,468 dengan p-value < 0,001 , average $R$-squared (ARS) sebesar 0,574 dengan p-value < 0,001, average adjusted $R$-squared (AARS) sebesar 0,568 dengan $p$-value $<0,001$, ini dapat diartikan bahwa model peneliti mempunyai fit yang baik. Kemudian diperoleh nilai average variance inflation factor (AVIF) sebesar 1,105 dan average full collinearity variance inflation factor (AFVIF) sebesar 1,725 <
3,3, ini dapat diartikan bahwa tidak ada masalah multikolonieritas antar indikator dan antar variabel eksogen.Selanjutnya diperoleh nilai tenenhaus goodness of fit $(\mathrm{GoF})$ sebesar $0,591>0,36$, ini menunjukkan bahwa kekuatan prediksi model adalah besar atau fit model sangat baik. Untuk mengevaluasi quality indexes dapatdilihat dari nilai indeks symson's paradox ratio (SPR) sebesar 1,000 > $0,70 \quad$ (dapat diterima). $R$-squared contribution ratio (RSCR) sebesar 1,000 $>0,90$ (dapat diterima), statistical 
suppression ratio (SSR) sebesar 1,000 > 0,70 (ideal), dan nonlinear bivariate causality direction ratio (NLBCDR) menghasilkan nilai $1,000>0,70$ (dapat diterima). Indeks-indeks tersebut bermakna tidak ada problem kausalitas didalam model.

Tabel 6. $R^{2}$ Coefficients

\begin{tabular}{|c|c|c|}
\hline Struktur & $\begin{array}{c}\text { R- } \\
\text { squared }\end{array}$ & $\begin{array}{c}\text { Adjusted R- } \\
\text { squared }\end{array}$ \\
\hline $\begin{array}{c}\text { Inklusi } \\
\text { Keuangan }\end{array}$ & 0,574 & 0,568 \\
\hline
\end{tabular}

Sumber: Data Olahan (2020)

Dari hasil tabel 6 di atas, diperoleh nilai $\mathrm{R}^{2}$ variabel inkluasi keuangan sebesar 0,574. Artinya adalah sebesar 57,4\% variabel inklusi keuangan dipengaruhi oleh literasi keuangan dan financial technology, sedangkan sisanya dipengaruhi oleh variabel lain.

\section{Pengujian Hipotesis}

\section{Gambar 2. Model Struktural}

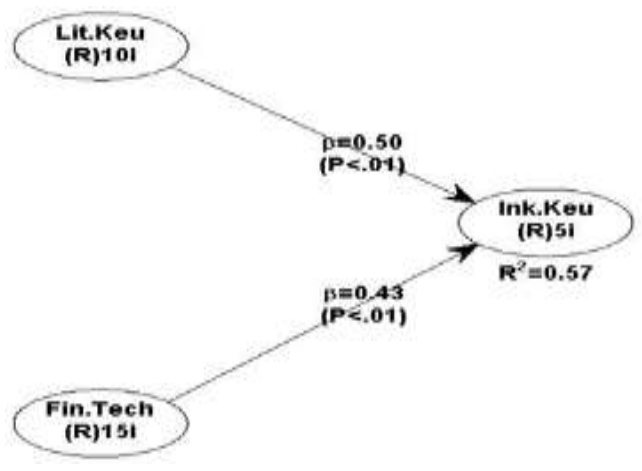

Sumber: Data Olahan (2020)

Berikut ini tabel hasil penelitian yang telah diperoleh berdasarkan pengolahan data:

Tabel 7. Hasil Uji Hipotesis

\begin{tabular}{|l|c|c|c|}
\hline \multicolumn{1}{|c|}{ Hipotesis } & $\begin{array}{c}\text { Path } \\
\text { Coefficients }\end{array}$ & $\begin{array}{c}\boldsymbol{P} \\
\text { Value }\end{array}$ & Keputusan \\
\hline $\begin{array}{l}\text { Lit.Keu } \rightarrow \\
\text { Ink.Keu }\end{array}$ & 0,501 & $<0,001$ & Diterima \\
\hline $\begin{array}{l}\text { Fin.Tech } \rightarrow \\
\text { Ink.Keu }\end{array}$ & 0,434 & $<0,001$ & Diterima \\
\hline
\end{tabular}

Sumber: Data Olahan (2020)
Dalam uji hipotesis variabel Literasi Keuangan terhadap Inklusi Keuangan diperoleh nilai koefisien path 0,501 yang menunjukan pengaruh positif yang artinya apabila Literasi Keuangan meningkat, maka Inklusi Keuangan akan meningkat. Nilai $p$ value $<0,001$ menunjukan pengaruh signifikan pada tingkat kepercayaan 5\%. Maka dapat disimpulkan bahwa hipotesis diterima, artinya literasi keuangan berpengaruh positif dan signifikan terhadap inklusi keuangan. Selanjutnya, uji hipotesis variabel Financial Technology terhadap Inklusi Keuangan diperoleh nilai koefisien path 0,434 yang menunjukan pengaruh positif yang artinya apabila Financial Technology meningkat, maka Inklusi Keuangan akan meningkat. Nilai $p$ value $<0,001$ menunjukan pengaruh signifikan pada tingkat kepercayaan 5\%. Maka dapat disimpulkan bahwa hipotesis diterima, artinya Financial Technology berpengaruh positif dan signifikan terhadap Inklusi Keuangan.

\section{Pembahasan}

\section{Pengaruh Literasi Keuangan terhadap Inklusi Keuangan}

\begin{abstract}
Bedasarkan hasil pengujian hipotesis variabel literasi keuangan terhadap inklusi keuangan menunjukan bahwa literasi keuangan berpengaruh positif dan signifikan terhadap inklusi keuangan. Hal ini menandakan bahwa semakin baik literasi keuangan seorang investor yang dilihat dari pengetahuan, sikap dan perilaku keuangannya akan meningkatkan penggunaan, pemanfaatan serta pemahaman produk dan layanan jasa investasi.
\end{abstract}

Hasil penelitian ini sejalan dengan penelitian yang dilakukan oleh OJK (2017) yang menyatakan bahwa literasi keuangan masyarakat akan diikuti dengan inklusi keuangan masyarakatnya. Dimana OJK menjelaskan bahwa pengetahuan dan keyakinan masyarakat terhadap lembaga 
jasa keuangan serta masyarakat yang terampil memanfaatkan produk dan layanan jasa keuangan, membutuhkan dukungan berupa ketersediaan akses kepada lembaga jasa keuangan, produk dan layanan jasa keuangan. Begitu pula implementasinya pada produk keuangan di pasar modal, khususnya pada produk investasi saham syariah. Seseorang yang telah memiliki pengetahuan mengenai investasi saham syariah serta yakin atau percaya terhadap saham syariah, dan juga terampil memanfaatkannya perlu didukung dengan ketersediaan akses yang mempermudah orang tersebut mengimplementasikan pengetahuan yang dimiliki. Sehingga hal ini akan meningkatkan pengguna produk investasi saham syariah di pasar modal.

Dalam penelitian OJK (2017) ditambahkan aspek sikap dan prilaku untuk menyempurnakan definisi dari literasi keuangan. OJK menyatakan bahwa sikap dan prilaku keuangan akan mendorong seseorang untuk menentukan tujuan keuangan, memiliki perencanaan keuangan, mengambil keputusan keuangan dan mengelola keuangan dengan lebih baik guna mencapai kesejahteraan. Sejalan dengan hasil penelitian ini, bedasarkan nilai loading factor tertinggi pada literasi keuangan, yaitu indikator Aktif Menabung yang terdapat pada dimensi financial behavior, dengan pernyataan "Tiap bulan saya menyisihkan pendapatan untuk berinvestasi di pasar modal" memiliki arti bahwa investor saham dengan literasi keuangan yang baik cenderung berprilaku menyisihkan pendapatannya untuk berinvestasi di pasar modal. Dengan adanya kegiatan menyisihkan pendapatan untuk berinvestasi pada pasar modal maka inklusi keuangan pada pasar modal akan meningkat.

\section{Pengaruh Financial Technology terhadap Inklusi Keuangan}

Bedasarkan hasil pengujian hipotesis variabel financial technology terhadap inklusi keuangan menunjukan bahwa literasi keuangan berpengaruh positif dan signifikan terhadap inklusi keuangan. Hasil ini menandakan bahwa semakin tinggi penggunaan financial technology, dalam hal ini penggunaan aplikasi online trading pada investor akan meningkatkan penggunaan, pemanfaatan serta pemahaman produk dan layanan jasa investasi.

Hasil penelitian ini sejalan dengan Kajian Bank Indonesia (2016) yang menjelaskan bahwa hadirnya fintech berupa inovasi pada sistem keuangan, akan mempermudah akses masyarakat dalam penggunaan dan pemanfaatan produk dan layanan jasa keuangan. Inovasi sistem keuangan berupa digitalisasi produk dan layanan mempermudah akses segala informasi terkait produk dan layanan jasa keuangan tanpa terkendala waktu dan ruang. Pada pasar modal, digitalisasi layanan dapat dilihat dari hadirnya online trading sistem sebagai alternatif perdagangan saham melalui aplikasi / platform secara online. Aplikasi online trading dapat meningkatkan inklusi keuangan pasar modal, sebab menggunakan jaringan internet yang luas dan dapat menjangkau masyarakat yang sebelumnya kesulitan dalam mengakses produk investasti saham. Oleh karena itu pesebaran produk pada pasar modal semakin luas, sehingga memungkinkan untuk menumbuhkan calon investor - investor baru dari berbagai wilayah.

Berbagai manfaat yang dapat dirasakan dengan tersedianya aplikasi online trading pada pasar modal, diantaranya dapat memudahkan dan mendekatkan investor untuk mengeksekusi produk secara mandiri dimana dan kapan saja, pembukaan rekening saham secara online tanpa mendatagi kantor perusahaan sekuritas, mengelola protofolio pribadi, memantau perkembangan harga saham dan kemudahan lainnya. Dimana kemudahaan ini akan menyebabkan 
efisiensi waktu dan biaya dari investor, karena tanpa harus datang langsung ke perusahaan terkait dan meniadakan fee broker untuk transaksi saham.

\section{Bedasarkan hasil nilai loading} factor tertinggi pada financial technology, indikator Ide yang Bagus sebagai penggunaan aplikasi online trading terdapat pada dimensi attitude toward using, dengan pernyataan "Menggunakan aplikasi online trading merupakan ide yang bagus" dimana dapat disimpulkan bahwa yang mempengaruhi investor menggunakan aplikasi online trading adalah sikap positif investor yang memilih penggunaan aplikasi online trading sebagai pilihan yang bagus untuk bertransaksi saham di pasar modal. Hal ini didukung dengan penelitian dari Lee (2009), yang menunjukan bahwa terdapat hubungan positif dari attitude toward using kepada minat investor menggunakan aplikasi online trading.

\section{Kesimpulan}

\section{Kesimpulan}

Hasil penelitian ini menunjukkan bahwa Literasi Keuangan berpengaruh positif signifikan terhadap Inklusi Keuangan. Sehingga apabila pemahaman Literasi Keuangan mengalami peningkatan, maka Inklusi
Keuangan akan mengalami peningkatan juga, begitu pula sebaliknya. Financial Technology juga berpengaruh positif signifikan terhadap Inklusi Keuangan yang artinya apabila Financial Technology mengalami peningkatan maka Inklusi Keuangan juga akan mengalami peningkatan.

\section{Rekomendasi Kebijakan}

Berdasarkan hasil penelitian dan pembahasan sebelumnya dapat ditarik beberapa rekomendasi kebijakan, antara lain: Sosialisasi mengenai literasi keuangan perlu untuk digiatkan agar semakin banyak masyarakat yang sadar akan investasi pada saham, sehingga semakin banyak masyarakat yang menyisihkan pendapatannya untuk berinvestasi di pasar modal membuat jumlah pengguna investasi saham di pasar modal pun meningkat. Selanjutnya, untuk perusahaan sekuritas yang menyediakan fasilitas online trading diharapkan meningkatkan kenyamanan bagi investor agar tumbuh perasaan positif investor saat menggunakannya, seperti memfasilitasi investor saham syariah dengan aplikasi online trading saham syariah yang terintegrasi prinsip syariah. Sehingga tidak ada keraguan bagi investor saham syariah menggunakan layanan trading online yang membuat meningkatnya pengguna saham syariah di pasar modal.

\section{APENDIKS - ITEM KUISIONER}

\begin{tabular}{|l|l|}
\hline \multicolumn{2}{|c|}{ Literasi Keuangan } \\
\hline Financial Knowledge & \multicolumn{1}{|l|}{$\begin{array}{l}\text { Harga 1 gram emas hari ini, lebih tinggi dari harga 1 gram emas 5 } \\
\text { tahun yang lalu }\end{array}$} \\
\hline $\begin{array}{l}\text { Rilai Waktu Uang dan } \\
\text { Keuntungan }\end{array}$ & $\begin{array}{l}\text { Investasi saham memiliki keuntungan yang besar dan resiko yang } \\
\text { tinggi }\end{array}$ \\
\hline Defenisi Inflasi & Inflasi yang tinggi berarti harga barang semakin tinggi \\
\hline Diversifikasi & $\begin{array}{l}\text { Membeli saham dari berbagai perusahaan akan mengurangi risiko } \\
\text { investasi dibandingkan dengan membeli saham 1 perusahaan saja }\end{array}$ \\
\hline Financial Behavior & $\begin{array}{l}\text { Tiap bulan saya menyisihkan pendapatan untuk berinvestasi di pasar } \\
\text { modal }\end{array}$ \\
\hline Aktif Menabung & Sebelum saya membeli suatu saham, saya mempertimbangkan
\end{tabular}




\begin{tabular}{|l|l|}
\hline \multicolumn{2}{|c|}{ Literasi Keuangan } \\
\hline Pembelian & berbagai hal mengenai saham perusahaan tersebut \\
\hline $\begin{array}{l}\text { Kengawasi Urusan } \\
\text { Keuangan }\end{array}$ & Saya mengelola urusan keuangan saya dengan teliti \\
\hline $\begin{array}{l}\text { Merencanakan } \\
\text { Tujuang Jangka } \\
\text { Panjang }\end{array}$ & $\begin{array}{l}\text { Saya menetapkan tujuan keuangan jangka panjang dan berusaha } \\
\text { mencapainya }\end{array}$ \\
\hline Memilih Produk & $\begin{array}{l}\text { Saya mempertimbangkan beberapa produk yang ditawarkan oleh } \\
\text { perusahaan yang berbeda sebelum melakukan transaksi }\end{array}$ \\
\hline Financial Attitude & \multicolumn{2}{|l|}{$\begin{array}{l}\text { Mempertibangkan } \\
\text { kebutuhan hari esok }\end{array}$} & $\begin{array}{l}\text { Saya tidak hanya mempertimbangkan kebutuhan hari ini tapi juga } \\
\text { mempertimbangkan kebutuhan hari esok }\end{array}$ \\
\hline
\end{tabular}

\begin{tabular}{|c|c|}
\hline \multicolumn{2}{|r|}{ Financial Technology } \\
\hline \multicolumn{2}{|l|}{ Perceived Ease of Use } \\
\hline $\begin{array}{l}\text { Mudah } \\
\text { Dioperasikan }\end{array}$ & Aplikasi online trading mudah untuk dioperasikan \\
\hline Tampilan Pengguna & $\begin{array}{l}\text { Desain aplikasi membuat Saya merasa tertarik untuk menggunakan } \\
\text { aplikasi online trading }\end{array}$ \\
\hline \multicolumn{2}{|l|}{ Perceived Usefulness } \\
\hline Akses Informasi & $\begin{array}{l}\text { Online trading bermanfaat untuk mencari informasi mengenai } \\
\text { investasi saham }\end{array}$ \\
\hline Efisiensi Biaya & Biaya transaksi melalui online trading itu sangat murah \\
\hline Efisiensi Waktu & $\begin{array}{l}\text { Kecepatan waktu dalam bertansaksi melalui aplikasi online trading } \\
\text { sangat cepat }\end{array}$ \\
\hline Efektivitas & $\begin{array}{l}\text { Menggunakan aplikasi online trading dapat meningkatkan efektivitas } \\
\text { dalam bertransaksi saham. }\end{array}$ \\
\hline \multicolumn{2}{|l|}{ Attitude Toward Using } \\
\hline $\begin{array}{l}\text { Pengalaman } \\
\text { Pengguna }\end{array}$ & Aplikasi online trading menyenangkan untuk digunakan \\
\hline Ide yang Bagus & Menggunakan aplikasi online trading merupakan ide yang bagus \\
\hline $\begin{array}{l}\text { Persepsi Kebutuhan } \\
\text { Individu }\end{array}$ & Penggunaan aplikasi online trading dinilai perlu \\
\hline \multicolumn{2}{|l|}{ Subjective Norm } \\
\hline Orang yang Penting & $\begin{array}{l}\text { Saya menggunakan aplikasi online trading bedasarkan saran orang } \\
\text { yang penting bagi Saya }\end{array}$ \\
\hline $\begin{array}{l}\text { Orang yang } \\
\text { Berpengaruh }\end{array}$ & $\begin{array}{l}\text { Saya terpengaruh menggunakan aplikasi online trading, karena } \\
\text { melihat keberhasilan orang lain menggunakan aplikasi online trading }\end{array}$ \\
\hline \multicolumn{2}{|r|}{ 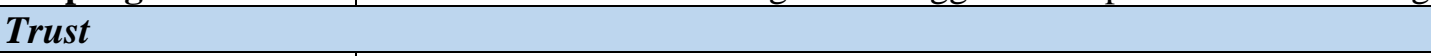 } \\
\hline Dapat Dipercaya & Penggunaan aplikasi online trading dapat dipercaya \\
\hline \multicolumn{2}{|l|}{ Perceived Risk } \\
\hline Informasi Probadi & Saya merasa tidak aman memberikan informasi personal di internet \\
\hline Kompensasi & $\begin{array}{l}\text { Saya khawatir tidak bisa mendapatkan kompensasi jika terjadi error } \\
\text { pada aplikasi online trading }\end{array}$ \\
\hline $\begin{array}{l}\text { Penipuan dan } \\
\text { Pembajakan }\end{array}$ & $\begin{array}{l}\text { Saya khawatir terjadinya penipuan atau intrusi hacker saat } \\
\text { bertransaksi saham secara online }\end{array}$ \\
\hline
\end{tabular}

\section{Inklusi Keuangan}


@Program Studi Manajemen

FE Universitas Maritim Raja Ali Haji

\begin{tabular}{|l|l|} 
produk keuangan & \\
\hline Product Awareness & \\
\hline $\begin{array}{l}\text { Kesalahan } \\
\text { pemilihan produk }\end{array}$ & $\begin{array}{l}\text { Saya memilih Reksa Dana Pasar Uang dibandingkan Obligasi untuk } \\
\text { investasi dengan jangka waktu kurang dari 1 tahun }\end{array}$ \\
\hline $\begin{array}{l}\text { Memahami tujuan } \\
\text { dan nilai potensial } \\
\text { produk }\end{array}$ & $\begin{array}{l}\text { Saya tahu berinvestasi pada saham mendapatkan dividen dan } \\
\text { kenaikan harga saham (capital gain) }\end{array}$ \\
\hline Product Choice & \\
\hline $\begin{array}{l}\text { Selalu memantau } \\
\text { produk Investasinya }\end{array}$ & Saya mengamati produk investasi Saya secara berkala \\
\hline $\begin{array}{l}\text { Mempertimbangkan } \\
\text { beralih produk / } \\
\text { layanan baru yang } \\
\text { tersedia atau saat } \\
\text { struktur berubah }\end{array}$ & $\begin{array}{l}\text { Saya selalu mencari tahu informasi mengenai produk atau layanan } \\
\text { baru yang tersedia di pasar modal }\end{array}$ \\
\hline
\end{tabular}

\section{Daftar Pustaka}

Allen., Franklin, Asli Demirguc-Kunt, Leora Klapper, Maria Soledad Martinez Peria (2016), The Foundations of Financial Inclusion: Understanding Ownership and Use of Formal Accounts. Journal of Financial Intermediation. doi: 10.1016/j.jfi.2015.12.003

Bank Indonesia (2016) Rancangan Peraturan Bank Indonesia tentang Penyelenggaraan Pemrosesan Transaksi Pembayaran. Jakarta: Bank Indonesia.

Bursa Efek Indonesia (2018), Indeks Saham Syariah. Jakarta: BEI.

Brown, Martin, \& Roman G. (2013), Financial Literacy and Retirement Planning in Switzerland. Numeracy 6, Iss. 2: Article 6. DOI: 10,5038/19364660,6.2.6

Dewan Syariah Nasional MUI (2002), Fatwa Dewan syariah No.4/DSNMUI/X/2003 tentang Pasar Modal dan Pedoman Umum Penerapan Prinsip Syariah di bidang Pasar Modal. [Internet]. [diunduh pada 2019 Des 29]. Tersedia pada: http://hukum.unsrat.ac.id/inst/dsn2003 40.pdf

Dhar, Vasant., Roger M. Stein (2017), FinTech Platforms and Strategy. MIT Sloan School of Management MIT Sloan School Working, p. 5183-16
Djawahir, Abdillah Ubaidi (2018), Teknologi-Layanan Keuangan, Literasi-Inklusi Keuangan, dan Value pada Fintech Syariah Di Indonesia: Perspektif S-O-R (Stimulus-OrganismResponse) Model.

Ghozali I. \& Latan H. (2015), Partial Least Squares Konsep, Teknik dan Aplikasi Menggunakan Program SmartPLS 3.0 (Ed. Ke-2). Badan Penerbit Universitas Diponegoro, Semarang.

Hair, J. F., Black, W. C., Babin, B. J., \& Anderson, R. E. (2014), Multivariate Data Analysis. London: Pearson.

Hutabarat, Febrina (2019) Pengaruh Literasi Keuangan dan Financial technology terhadap Inklusi Keuangan pada Masyarakat Jabodetabek. [skripsi]. Bogor [ID]: Institut Pertanian Bogor

Kardinal (2017), Pengaruh Literasi Keuangan Terhadap Penggunaan Produk Keuangan Pada Mahasiswa STIE Multi Data Palembang. Forum Bisnis Dan Kewirausahaan Jurnal Ilmiah STIE MDP.

Lee, Ming-Chi (2009), Predicting Explaining The Adoption of Online Trading: An Empirical Study In Taiwan. Decision Support System Vol 47, p. 133-142

Lestari, Sri. (2015), Literasi Keuangan Serta Penggunaan Produk Dan Jasa Lembaga Keuangan. Jurnal Fokus Bisnis, Vol. 14, No 02. 
Makarov, Dmitry and Schornick, Astrid V., Explaining Households' Investment Behavior (2010), INSEAD Working Paper No. 2010/44/FIN, Availabe at SSRN: https://ssrn.com/abstract=1623785 or $\underline{\mathrm{h}}$ ttp://dx.doi.org/10.2139/ssrn.1623785

Organization for Economics Cooperation Development (2016), Measuring Financial Literacy: Questionnaire and Guidance Notes for Conducting an Internationally Comparable Survey of Financial Literacy. INFE.

Otoritas Jasa Keuangan (2016), Survei Nasional Literasi dan Keuangan Inklusi Keuangan 2016. Jakarta (ID) : OJK.

Otoritas Jasa Keuangan (2017), Revisit Strategi Nasional Literasi Keuangan Indonesia. Jakarta (ID) : OJK.

Otoritas Jasa Keuangan (2017), Kuliah Umum tentang Financial Technology di Indonesia. Jakarta (ID) : OJK.

Presiden Republik Indonesia (2016), Peraturan Presiden Republik Indonesia No. 82 Tahun 2016 tentang Strategi Nasional Keuangan Inklusif. Lembaran Negara Republik Indoensia Tahun 2016 Nomor 185

Pemerintah Indonesia (1995) Undang Undang Republik Indonesia No. 8 tahun 1995 tentang Pasar Modal. Lembaran Negara Republik Indonesia Tahun 1995 Nomor 64.

Putri, Wahyu Nurriska Dwi (2019) Pengaruh Behavioral Finance Dan Financial Literacy Terhadap Investment Intention Investor Saham Di Indonesia. [skripsi]. Jakarta. [ID]: Universitas Indonesia
Ramayah, T., Kamel Rouibah, M. Gopi, Gary Jhon Rangel (2009), A decomposed theory of reasoned action to explain intention to use internet stock trading among Malaysian investors. Computers in Human Behavior Vol.25, p. 1222-1230

Roca, Juan Carlos, Juan José García, Juan José de la Vega (2009), The importance of perceived trust, security and privacy in online trading systems. Information Management \& Computer Security, Vol. 17, No. 2, p. 96 - 113.

Sivaramakrishnan, S., Srivastava, M., \& Rastogi, A. (2017), Attitudinal factors, financial literacy, and stock market participation. International Journal of Bank Marketing, Vol.35, No. 5, p. 818-841

Van Rooij, M., Lusardi, A. \& Alessie, R. (2011), Financial Literacy and Stock Market Participation. Journal of Financial Economics, Vol. 101, No. 2, pp. 449-472.

Xu, Lisa., Bilal Zu. (2016) Financial Literacy around the World: An Overview of the Evidence with Practical Suggestions for the Way Forward. Policy Research Working Paper 6107. The World Bank Development Research Group Finance and Private Sector Development Team.

Yoong, J. (2011), Financial illiteracy and stock market participation: Evidence from the RAND American Life Panel. Financial literacy: Implications for retirement security and the financial marketplace, p. 76. 